Abstracta Iranica Abstracta Iranica

Revue bibliographique pour le domaine irano-aryen

Volume 22 | 2001

Comptes rendus des publications de 1999

Being and Existence in Șadrâ and Heidegger. A Comparative Ontology. Tranlated into Persian by M. R. Jawzi, Wisdom of Persia Series XXXXVII, Tehran, 1999, 222 p., index persan-anglais, bibliographie.

Christian Jambet

2 OpenEdition

Édition électronique

URL : http://journals.openedition.org/abstractairanica/36884

DOI : 10.4000/abstractairanica.36884

ISSN : 1961-960X

Éditeur :

CNRS (UMR 7528 Mondes iraniens et indiens), Éditions de l'IFRI

Édition imprimée

Date de publication : 15 mai 2001

ISSN : 0240-8910

Référence électronique

Christian Jambet, « Being and Existence in Șadrâ and Heidegger. A Comparative Ontology. Tranlated into Persian by M. R. Jawzi, Wisdom of Persia Series XXXXVII, Tehran, 1999, 222 p., index persan-anglais, bibliographie. », Abstracta Iranica [En ligne], Volume 22 | 2001, document 404, mis en ligne le 17 février 2010, consulté le 13 octobre 2020. URL : http://journals.openedition.org/abstractairanica/36884

DOI : https://doi.org/10.4000/abstractairanica.36884

Ce document a été généré automatiquement le 13 octobre 2020.

Tous droits réservés 


\title{
Being and Existence in Șadrâ and Heidegger. A Comparative Ontology. Tranlated into Persian by M. R. Jawzi, Wisdom of Persia Series XXXXVII, Tehran, 1999, 222 p., index persan-anglais, bibliographie.
}

\author{
Christian Jambet
}

1 La métaphysique de Mollā Șadrā est fondée sur la primauté de l'acte d'être (wojūd) et conçoit le philosophe comme «témoin de l'être " (Šăhid al-wojūd). Il n'est donc pas surprenant qu'elle soit comparée à l'analyse existentiale de $M$. Heidegger. Après avoir longuement analysé le sens du concept d'existence chez Mollā Șadrā, et rappelé ce qu'est le Dasein heideggerien, l'A. propose des analyses pertinentes de l'être concret et de l'être de pure pensée (dihnī) et met en lumière les difficultés et les apories de la question de l'être, sans oublier le statut de la réalité-humaine. Certes, cette comparaison réglée et instruite suscite un doute: peut-on mettre en rapport une ontologie foncièrement dépendante d'Avicenne, jusqu'en ses critiques de l'avicennisme, et la démarche de Heidegger? Du moins l'A. a-t-il le mérite d'assumer jusqu'au bout le choix de passer outre l'écart si considérable des problématiques. 
INDEX

Thèmes : 9. Philosophie

\section{AUTEURS}

CHRISTIAN JAMBET

Paris 